The Polish Journal of the Arts and Culture. New Series 13

(1/2021): 109-131 [ARTICLE]

DOI: $10.4467 / 24506249$ PJ.21.006.13733

\title{
"Six Things Are Said Concerning Demons" (Hagigah 16a). The System of Topic Tags Used in the Elyonim veTachtonim Inventory to Describe the Features of Supernatural Entities and Their Relationships with Humans*
}

\author{
Wojciech Kosion
}

\begin{abstract}
This paper has two main purposes: to outline the methodology underlying the tag ontology utilised in the Elyonim veTachtonim inventory and to demonstrate the system of topic tags used to designate recurring subjects recognised in the accounts involving supernatural entities.

Keywords: Digital Humanities, Babylonian Talmud, angelology, demonology

Wojciech Kosion a graduate of Psychology, Religious Studies and Jewish Studies, adjunct at the Centre for Comparative Studies of Civilisations (Jagiellonian University). He is currently working on the Elyonim veTachtonim - an inventory of angels, demons, ghosts and monsters in early rabbinic literature (https://elyonimvetachtonim.project.uj.edu.pl/).

(iD https://orcid.org/0000-0002-1555-5952

E-MAIL: wojciech.kosior@uj.edu.pl
\end{abstract}

This paper was written as a part of the project The Supernatural Entities and Their Relationships with Humans according to the Babylonian Talmud from the Quantitative and Qualitative Perspectives financed by the National Science Centre, Poland (SONATA 14; Registration number: 2018/31/D/HS1/00513). 


\section{Introduction}

Elyonim veTachtonim [hereinafter: EvT], Hebrew for "those above and those below" and a merism for the supernatural and natural divine creation, is the codename for an inventory of supernatural entities [hereinafter: SE] in early rabbinic literature (Elyonim veTachtonim, 2017). The database is fashioned as a spreadsheet document in Excel Binary File Format (.xlsx) and contains portions of source text featuring a given SE. Each portion (a "unit") is annotated using a complex tagging system. The inventory serves not only as a thematic concordance but also, thanks to the partition into textual units, facilitates various calculations (e.g., correlations between literary genre and a given type of SE) and the creation of data models (e.g., distribution of a given type of SE across the corpus). As such it supplements the traditional qualitative methods of the humanities with digital quantitative ones. ${ }^{1}$

The project was initiated in 2016. The first version of the database was published in 2017 and since then there have been five essential updates featuring more units, a wider range of SEs and a more intricate system of annotation. The current version oo6, codenamed Uzzah was published in 2021 and marks the solidification of the tag ontology used in the study of the Babylonian Talmud [hereinafter: BT]. The present paper - apart from commemorating this important milestone - has two main purposes: to outline the methodology underlying the annotation and to demonstrate the detailed account of the topic tags used in the EvT project. As such this paper is intended primarily for both present and future users of the EvT database who desire a more profound exposition of the system behind the inventory and would like to know the nuances of the classification process. Given the very flexible nature of the project, the present article also serves as a point of reference for scholars wishing to construe a similar database within the framework of some other cultural and religious tradition.

\section{Methodology}

The essential component of the EvT project is the database, hereby understood as a structured collection of data along with the methods of access, organisation, selection and retrieval (Flanders, Jannidis 2020, 315; Rydberg-

1 For the benefits of deploying digital methods in the humanities see for instance: Berry 2012, 2-3; Hayles 2012, 43-44; Wilkens 2012, 249-258; Neilson, Levenberg, Rheams 2018, 7. 
-Cox 2006, 15). The structure of a given database follows from the specific knowledge organisation system which relies on three processes:

- classification - a grouping of elements which share some property into sets and distinguish them from other elements sharing different properties;

- ontology - a formalised and hierarchised system of all elements such as actors, items and actions, together with their properties and relationships;

- taxonomy - a naming system used in the ontology, operating with a controlled vocabulary (Crofts et al. 2011, ix-xviii; Eide, Smith Ore 2020, 181-183, 187; Flanders, Jannidis 2020, 325; Hughes, Constantopoulos, Dallas 2016, 163; Sperberg-McQueen 2016, 377, 381-383).

The basic tool of the knowledge organisation system used in the EvT inventory is tag - an index (metadata) given to a specific piece of information, which in turn facilitates searching, collecting, and counting (Drucker et al. 2014, 46; Fiormonte 2015, 145, 155; Flanders, Jannidis 2020, 322; McGann 2016, 358-359). The EvT ontology contains over 300 tags which are grouped into several categories: class and type of SE, grammatical number, literary genre, topic, and the attitude of the SE towards humans. The choice of these categories follows from the basic theoretical and methodological assumptions governing the EvT project: in short, SEs are approached along the lines of the cognitive science of religion, as anthropomorphic beings who engage in all kinds of social interactions with humans and, due to the nature of the medium, are analysed in the framework of their literary context (Kosior 2017, especially 93-95). Categories of topic, class and entity allow for a multi-class classification: several tags can be assigned to a given unit simultaneously. Categories of genre, grammatical number and attitude permit single-class classification: only one tag of a given category can be assigned to a given unit. In the present version of the database, each category is mandatory for every unit. At earlier stages of the database development, the annotation system had a more folksonomic nature, but ultimately the classification scheme became enumerated and all the tags used in the project are listed and operationalised. ${ }^{2}$ In order to maintain consistency, both the operationalisation and classification processes were performed by one person, with numerous revisions.

2 As aptly noted by one anonymous reviewer, the term "tag" is oftentimes understood as a label which can be freely assigned to datasets without necessarily being organised in a hierarchical system - hence, perhaps a different term would be more appropriate here. On the other hand, it has been used in the EvT project since its inception and even though the classification system became quite rigid, we decided to keep "tag" for the sake of consistency in terminology. 
The terms used as tag-labels have been coined to be as informative as possible even if that meant devising a neologism (e.g., \#angelogony, \#pneumogony), using a term from a different cultural entourage (e.g., \#apocatastasis, \#demiurge) or a less popular word (e.g., \#fulmination, \#precipitation). Since the Excel file format does not offer tagging functionality in vanilla mode, ${ }^{3}$ a decision was made to input labels as strings of characters in appropriate cells. This meant that, in order to avoid confusion in calculations, unique names had to be invented, e.g., \#abodeofdead alongside \#underworld, \#hurt alongside \#affliction, \#food alongside \#cuisine, etc.

The database is governed by the open-world assumption stating that the information stored in the knowledge system is incomplete relative to the realm it describes (Crofts et al. 2011, ix-xviii; Sperberg-McQueen 2016, 384387,389 ). Hence, the annotation system is malleable and has numerous "pegs" for potential future extensions within already existing domains, such as anthropomorphic descriptions of SEs or magical and theurgical tools for influencing SEs. Given the abstract nature of the system, it is adaptable to different cultural and religious contexts and can easily accommodate not only different SEs but also different literary genres, or even totally different mediums. ${ }^{4}$

The ontology contains over 150 topic tags, which are presented below. They are organised into a multidimensional classification with a hierarchy of increasingly fine distinctions, arranged into a several-tier structure. The subsequent tiers of tags are hereby marked by tab. indentations: first tier - no indentation, second tier - one tab, third tier - two tabs, etc. The tags belonging to the first tier are presented thematically, while the tags belonging to the second tier and above are presented alphabetically. Every topic is defined by means of an abstract ideal type - a "schema" (Hogan 2003, 57-59), which in most cases is readily translatable into Hebrew and Aramaic, the original

3 The lack of the out-of-the-box tagging functionality is just one of Excel's limitations and throughout the development of the project alternative solutions were contemplated. Ultimately, however, we decided to stick with it for two main reasons. First, it has been in use since 1980s and it can be edited using a broad range of free software, which guarantees its sustainability and compatibility in the future. Second, it provides a reasonable balance between functionality and ease of use, thus allowing even the less experienced users for performing various operations, especially these pertaining to data visualisation. Due to the cooperative potential of the project, this latter argument is all the more valid. Still, this does not preclude the prospect of exchanging it or supplementing with a different format.

${ }^{4}$ For the examples see the "Legacy" tab. on Elyonim veTachtonim 2017. 
languages of the BT. ${ }^{5}$ While each tag belonging to the second tier and above is supplemented with one to three paradigmatic examples, the reader is sincerely recommended to use the spreadsheet filtering function to see more illustrations. Although the outline has been prepared basing on the version 006 Uzzah of the inventory the system is mostly compatible with the previous versions. The transcription used throughout this paper conforms to the rules of the EvT project (Elyonim veTachtonim 2017), all the tags are distinguished with a hashtag symbol (e.g. \#apotropaic) and retain the orthography adhered to in the database (hence "\#characterization" and not "characterisation"). For the sake of accessibility, the names of the particular SEs found in the examples are translated or paraphrased rather than transcribed.

\section{Features of the SEs}

The topics recognised in the database can be roughly divided into two groups. The first group includes tags which pertain specifically to the qualities possessed by the SEs.

\#aboutentities - the unit speaks about the abstract features of an SE.

- \#appellation - the name of an SE appears as a part of a divine appellation, e.g., the phrase "Yahweh of hosts" (Heb. Yahweh tzevaot) (Shabbat 25b, 32b, Hagigah 15b-16a, Avodah Zarah 3b, Hullin 91b) or "Yahweh of hosts who dwells among cherubs" (Berakhot 49b-50a and Bava Batra 14b).

- \#hierarchy - the unit speaks about the ranking of the SEs, both internal and in universal chain of beings, e.g., Berakhot $4 \mathrm{~b}$ juxtaposes the skills of Gabriel, Michael and the angel of death; Hagigah 13a lists the grades of the angels inhabiting heavens.

\# council - the deity consults certain matters with a lesser SE, e.g., in Bava Batra 15b-16a the god discusses Job with Satan, while in Sanhedrin $38 \mathrm{~b}$ he holds council with the ministering angels before creating humans.

\#cult - an SE is distinguished by being the addressee of exaltation and sacrifices, e.g., Avodah Zarah $42 \mathrm{~b}$ and Hullin 4 oa speak about offerings to Michael; Sanhedrin 61a, Avodah Zarah 51a-b and Zevahim 106a recall the biblical tradition of the oblations to the satyrs (Heb. seirim, Leviticus 17:7).

\footnotetext{
5 Such basic test of the etic categories' adequacy has been inspired by Wierzbicka 1999; 2014.
} 
\#praise - an SE praises the deity, e.g., Hagigah $12 \mathrm{~b}-15 \mathrm{~b}$ describes a ceremony involving heavenly angels and earthly monsters; in Hullin 6oa angelic prince of the world (Heb. sar olam) proclaims the divine glory.

- \#hybrid - an SE is denoted with various terms signifying different types or classes, e.g., Eruvin 43a and Pesahim 110a speak about a demon (Heb. shed) named Yosef in a way which suggests that this is a ghost of a deceased human; Qiddushin 29b describes a demon-monster hybrid haunting the school of Rabbi Abaye.

- \#identification - an SE is identified (directly or indirectly) with another one or as belonging to a given type, e.g., Berakhot 51a and Bava Batra 16a identify the angel of death with Satan, Keritot $3 \mathrm{~b}$ identifies a familiar spirit (Heb. ov) with a demon, Rosh HaShana 24b and Hagigah $13 \mathrm{~b}$ identify the four-faced angels (Heb. arbaa panim) with the living beings (Heb. chayot) of the Book of Ezekiel.

- \#image - the unit speaks about an artificial representation of an SE, e.g., the sculptures of cherubs in the temple (Yoma 21b, 54a-b, Sukkah $5 \mathrm{a}-\mathrm{b}$ ) and a figurine of a dragon (Avodah Zarah 42a-43b).

- \#stealth - an SE can be sensed, recognised, or interacted with only under special circumstances or solely by a certain human. E.g., in Berakhot 6a humans cannot see the demons but only their footprints; Megillah $11 \mathrm{~b}-16 \mathrm{~b}$ introduces covert SEs in the retelling of the Book of Esther.

- \#proverbial - an SE is used as or in a figure of speech, e.g., Berakhot 19b, 6oa, Ketubbot 8b warn against "opening one's mouth to Satan"; Berakhot 25b, Qiddushin 54a, Meilah 14b stress that the "Torah has not been given to the ministering angels."

- \#teaching - a piece of information transmitted in the unit is put in the mouth of an SE, e.g., the tradition about Asmodeus who is appointed over pairs is conveyed by Yosef the demon in Pesahim 110a; the tradition about the shadows cast by the demons is supplied by Yonatan the demon in Gittin 66a.

\#description - the unit contains a depiction of the morphological qualities of an SE:

6 A special case of combination of the \#stealth and \#proverbial tags comes in the units which deploy the angel of death (e.g. Nedarim 41a-b, Hullin 7b, Niddah 71a) in a manner which does not allow to tell, whether it is used literally or figuratively. Due to this ambiguity such units have been labelled with both tags. 
- \#comparison - an analogy is drawn between an SE and human, animal, or inanimate phenomenon.

- \#anthropomorphic - an SE is compared to a human, e.g., in Hagigah $14 \mathrm{~b}$ the ministering angels congregate like humans to listen to the discussion of rabbis Joshua and Jose; in Hagigah 15a Metatron is a scribe writing down the merits of Israel; in Gittin 68a Asmodeus betrays his weak spot for sensual indulgences.

\#reification - an SE is compared to some inanimate object or phenomena, e.g., Pesahim 111b likens demon Keteb to a clay vessel or a goat's horn; Berakhot 61a implicitly compares humans' inclinations (Heb. yetzarim) to kidneys.

- \#simile - a human is compared to an SE. E.g., Shabbat $112 b$ likens scholars to angels; Eruvin 1oob compares women to Lilith.

- \#theriomorphic - an SE is compared to an animal or possesses animal features. E.g., Berakhot 61a compares a yetzer to a fly; in Sukkah $5 \mathrm{~b}$ cherubs possess wings; Taanit $25 \mathrm{~b}$ describes angel Ridya as a three-year-old heifer. ${ }^{7}$

- \#perception - the portrayal of an SE puts emphasis on the specific modus of perception.

- \#audial - the audial features of an SE are considered, e.g., Yoma 2ob-21a analyses the sounds made by Ridya.

- \#olfactory - the odours emitted by an SE are considered, e.g., Bava Batra $74 \mathrm{~b}$ describes the stench of the angelic prince of the Sea of Reeds; in Sanhedrin 95b Gabriel has lethal breath.

- \#visual - the appearance of an SE is considered. E.g., Shabbat $25 \mathrm{~b}$ describes the garments of Rabbi Judah bar Ilai which make him resemble angel of Yahweh; Menahot 99b-100a describes the narrow mouth of Gehenna.

- \#characterization - the unit speaks about the specific details of an SE's appearance.

\footnotetext{
The \#anthropomorphic and \#theriomorphic tags can be used in conjunction when the qualities of both humans and animals are acknowledged in the description of an SE (e.g., Hagigah 16a outlines similarities between humans, animals, angels and demons; Bava Batra 99a portrays cherubs as human-animal amalgam) or the qualities of an SE fit both humans and animals (e.g., Niddah 22b and 24b draws an analogy between aborted foetuses, sea-monsters and Lilith; in Eruvin 41b and Menahot 99b-100a Gehenna is said to have a mouth (Heb. pi), yet given its voracity it cannot be unambiguously decided whether the oral cavity belongs to a human or to an animal).
} 
○ \#accessories - an SE possesses some items, e.g., in Sanhedrin 95b Gabriel brandishes a scythe; in Bava Qamma 6ob in times of plague the angel of death keeps his tools in a synagogue, while in Arakhin 7 a he is equipped with poison.

o \#chameleon - an SE can alter its appearance, e.g., in Yoma 75a demons change their colour of skin.

\#colossus - an SE is massive, e.g., sculptures of cherubs in Sukkah 5b, Megillah 1ob and Bava Batra 99a; angel Sandalfon in Hagigah 13b; monsters encountered by rabbis in Bava Batra $73 \mathrm{~b}$.

- \#disguise - an SE appears in camouflage, e.g., in Taanit 24b angels show up as sailors; in Qiddushin 81a Satan impersonates a woman, while in Sanhedrin 95a he morphs into a deer. ${ }^{8}$

\#multitude - SEs are exceedingly numerous, e.g., in Gittin 68a Rabbi Yohanan claims that there are three hundred kinds of demons in Shihin (a village in Galilee), while in Sanhedrin 98b he acknowledges the size of the heavenly family (Heb. familia shel maaleh).

\#nature - the unit speaks about the nature of an SE., e.g., demons can be both male and female (Gittin 68a); the yetzer has a variety of stratagems to entice humans (Sukkah $52 \mathrm{~b}$ ).

- \#physiology - the unit speaks about physiology of an SE, e.g., the ministering angels do not need to defecate (Yoma $4 \mathrm{a}-\mathrm{b}$ ).

$\diamond$ \#eating - an SE eats, e.g., in Bava Metzia 86b the ministering angels consume bread.

$\diamond$ \#crying - an SE cries, e.g., in Hagigah 5 b the angels of peace mourn for the destruction of the Jerusalem temple; in Hullin 92a an angel weeps after being defeated by Jacob.

$\diamond$ \#copulating - an SE copulate, e.g., according to Shabbat $145 \mathrm{~b}-146 \mathrm{a}$ and Yevamot $103 \mathrm{~b}$ the ancient serpent cohabited with Eve.

- \#onomastic - the unit explains the meaning of an SE's name, e.g., Sukkah $5 \mathrm{~b}$ and Hagigah 13b interpret the word "cherub" as a contraction of kerabiah (Aram. "as a child"), what explains its juvenile face; Eruvin 19a lists other appellations of Gehenna.

8 This tag has to be differentiated from \#stealth. An SE marked with \#disguise remains perceptible, although not recognised as one, while an SE marked with \#stealth remains imperceptible until some conditions are met. 
- \#voracity - an SE is ravenous, e.g., in Nedarim 32a Moses is swallowed by angels; Bava Batra 75a attributes Leviathan with an insatiable appetite.

\#proficiency - an SE has knowledge or skills, important for humans' wellbeing or essential from the human perspective:

- \#dominion - an SE has power over a certain domain.

- \#aquatic - an SE controls the flow of water, e.g., in Pesahim 118b and Arakhin 15a angelic prince of the sea spits out the dead Egyptians drowned in the Sea of Reeds; in Taanit 25b the depths (Heb. tehomot) supply the springs with water.

\#precipitation - an SE controls precipitation, e.g., Ridya causes rain in Yoma 2ob-21a while Yurqami the prince governs over hail in Pesahim 118a-b.

- \#fire - an SE controls fire, e.g., Gabriel has power over fire (Pesahim $118 \mathrm{a}-\mathrm{b}$ and Yoma 21b); the living creatures (Heb. chayot) are of fiery essence (Hagigah 13a-b).

\#fulmination - an SE controls lightning and storm, e.g., the chayot take the form of lightings in Hagigah $13 \mathrm{~b}$.

- \#temperature - an SE evokes low or high temperatures, e.g., angels in Sanhedrin 108b.

\#wind - an SE controls the flow of air, e.g., an angelic "son of hawk" (Heb. ben netz) keeps the hurricanes from devastating the earth in Gittin 31b.

- \#knowledge - an SE possesses important knowledge.

- \#angelology - the knowledge concerns angels, e.g., the angel of death announces his custom of preceding the funeral procession in Berakhot 51a and betrays the surgical details of his craft in Avodah Zarah 2ob.

- \#anthropology - the knowledge concerns humans, e.g., the ministering angels in Nedarim $20 a-b$ teach about the effects of various sexual acts performed by the parents on the properties of their soon-to-be child.

- \#cosmology - the knowledge concerns the world, e.g., in Bava Batra 73 b the divine "daughter of the voice" (Heb. bat qol) knows earth's topography.

- \#demonology - the knowledge concerns the demons, e.g., Yonatan and Yosef describe the demons to humans (Yevamot 122a or Gittin 66a) and teach them protective measures (Pesahim 110a). 
- \#divination - the contents of knowledge are not specified, e.g., humans consult ghosts (Berakhot 21b and Sanhedrin 54a), and demons (Sanhedrin 67b and 101a).

\#future - the knowledge concerns the prospective events, e.g., in Gittin 68a-b Asmodeus knows the fate of various humans; bat qol tells humans their fortune in Berakhot 61b and Shabbat $56 \mathrm{~b}$.

\#halakhist - the knowledge concerns halakhah, e.g., the holy spirit (Heb. ruach qodesh) teaches Rabbi Gamaliel in Eruvin 64b; the ministering angels inform Rabbi Johanan in Nedarim $20 a$.

\#linguistic - the knowledge concerns lingual matters, e.g., in Sotah 33a and 36b Gabriel teaches Joseph seventy languages; the demons have their own dialect (Bava Batra 134a).

- \#prophecy - an SE transmits orders from a deity or causes a human to prophesy in the name of a deity, e.g., in Berakhot $4 \mathrm{~b}$ and 1oa the holy spirit grants access to the divine secrets; Sanhedrin 93b lists qualities transmitted by various divinely ordained SEs.

\#secret - the knowledge is labelled as covert and its contents are not specified, e.g., in Shabbat 89a the angel of death betrays his secrets to Moses; in Megillah za and Sotah 1ob bat qol shares her mysteries with humans.

- \#wealth - the knowledge concerns the location of material goods, e.g., in Berakhot $18 \mathrm{~b}$ ghosts are consulted in search for treasures; in Bava Batra $74 \mathrm{~b}$ a tanin is protecting a gem.

- \#skill - an SE has an important skill:

- \#agility - an SE is swift and dexterous, e.g., in Gittin 68a Asmodeus travels between earthly and heavenly academies; Bava Batra 73a-b portrays Hormin son of Lilith as an exquisite acrobat.

\#craftsmanship - an SE is skilled in a specific craft, e.g., in Sotah $48 \mathrm{~b}$ and Gittin 68a-b shamir, a monster-worm, is capable of carving building blocks out of rock; in Bava Batra 75a and Sanhedrin $100 a$ the angels cut precious stones and pearls.

- \#demiurge - an SE creates some part of the world, e.g., Gabriel prepares the land for the Roman Empire by planting a reed in the sea (Shabbat $56 \mathrm{~b}$ and Sanhedrin 21b).

- \#doctor - an SE has medical skills, e.g., in Gittin 68b Asmodeus provides Solomon with a remedy for overeating and hangover. 
- \#military - an SE has martial skills, e.g., in Sanhedrin 94a-b angel of Yahweh eradicates the army of Sennacherib; in Megillah 11b Satan assassinates Queen Vashti.

- \#undead - an SE belonging to the class of ghosts manifests full set of cognitive skills, e.g., in Shabbat $152 \mathrm{~b}$ a dead human is still conscious until put into the grave and covered with a stone.

\#virtue - an SE has an unspecified skill, e.g., in Sanhedrin 67b the demons are the tools of a magician.

\#habitation - the unit speaks about the spatial and temporal whereabouts of an SE:

- \#abodeofdead - an SE inhabits the land of the deceased, e.g., Bava Batra 79a locates the revenants (Heb. refaim) in Sheol.

- \#animal - an SE inhabits the body of an animal, e.g., in Yoma 83b-84a an evil spirit (Heb. ruach raah) rests upon a mad dog; Berakhot 33a and Pesahim 112b employ a proverbial expression about Satan dancing between ox's horns. ${ }^{9}$

- \#baths - an SE inhabits a bathhouse, e.g., Berakhot 6oa warns against "opening one's mouth for Satan" upon entering a bathhouse.

- \#body - an SE inhabits a human body or its close vicinities, e.g., the ministering angels constantly accompany every human; (Shabbat $119 \mathrm{~b}$ and Taanit 11a); Berakhot 61a and Nedarim 32b locate the yetzer within various parts of human corpus.

- \#bridge - an SE inhabits a bridge, e.g., in Shabbat 32a Rabbi Samuel utters "Satan has no power over two nations simultaneously" while crossing a bridge and passing by a heathen.

- \#cemetery - an SE inhabits a burial ground, e.g., Shabbat 152b locates there the ghosts of the deceased humans; Hagigah $3 \mathrm{~b}$, Sanhedrin $65 \mathrm{~b}$ and Niddah 17a present it as an abode of the unclean spirit (Heb. ruach tumaah).

- \#everywhere - an SE is omnipresent, e.g., in Berakhot 6a demons are considered to be everywhere; Bava Batra 25a affirms the ever presence of angels.

- \#food - an SE inhabits comestibles, e.g., Niddah 17 lists countermeasures against evil spirit infecting food; in Ketubbot 61a-b Rabbi Ashi

9 It is nearly impossible to know whether these expressions were treated as literal and therefore they should be interpreted primarily as drawing semantic associations between an SE mentioned in the proverb and the circumstances. See also subsequent cases involving Satan in Berakhot: $60 \mathrm{a}$, and Shabbat: $32 \mathrm{a}$. 
recognises the spirit of psoriasis (Heb. ruach tzaraat) floating over a dish.

- \#heaven - an SE inhabits celestial realms, e.g., Berakhot 10a, Yoma 77a locate various angels in heavens.

- \#throne - an SE inhabits the proximity of the divine chair, e.g., in Shabbat $152 \mathrm{~b}$ the souls of the righteous are hidden under the throne.

- \#house - an SE inhabits human's dwelling, e.g., Pesahim 111b speaks about home angels of cleanness and dirt; Shabbat 151b locates Lilith in empty houses; in Sotah 48a and Bava Qamma 21a demon sheiyah resides at thresholds.

- \#mountains - an SE inhabits mountains, e.g., in Gittin 68a Asmodeus has his abode on a peak; in Bava Batra 74 b Behemoth dwells on "thousand hills."

- \#night - an SE is nocturnal, e.g., an evil spirit shows up at night (Berakhot 43b, Shabbat 29b); in Pesahim 112b demoness Igrath bat Mahalath and her angels have the authority to assault humans at night; in Nedarim 31b-32a various angels attack Moses and his family at night.

- \#palace - an SE inhabits a royal building, e.g., in Shabbat 149b King Nebuchadnezzer's palace is destined to become the satyrs' abode.

- \#privy - an SE inhabits a toilet, e.g., in Berakhot 62a Rabbi Tanchum advises to behave modestly in the lavatory to repel demons dwelling therein; Shabbat 67a recognises bar shirika panda as one of the privy demons.

- \#road - an SE inhabits a road, e.g., in times of plague the angel of death struts the main highways (Bava Qamma 6ob).

- \#ruins - an SE inhabits abandoned places, e.g., Berakhot 3a-b warns against demons living in the ruins.

- \#school - an SE inhabits a school or academy, e.g., in Bava Metzia 59b bat qol engages there in harsh halakhic dispute with the rabbis.

- \#shades - an SE inhabits shadows, e.g., Pesahim 111b advises avoiding shadows so as not to stumble upon the demons.

- \#synagogue - an SE inhabits a synagogue, e.g., in times of plague this is a temporary residence of the angel of death (Bava Qamma 6ob).

- \#temple - an SE inhabits the Jerusalem temple, e.g., this is the locale of cherubs in Yoma 21a-b, while Berakhot 7a, Sotah 33a and Zevahim 62a locate there other angels.

- \#trees - an SE resides among trees and bushes, e.g., Pesahim 111b distinguishes various types of demons dwelling in the woods. 
- \#water - an SE inhabits water, e.g., an evil spirit resides in the water spilt on the ground after the ablution ritual (Hullin 105b); Leviathan and the prince of the sea dwell in the ocean (Bava Batra 74b and Arakhin 15a). \#genesis - the unit speaks about the creation of SEs, ranging from their physical formation up to their designation to specific functions:

- \#angelogony - the unit speaks about the creation of an angel, e.g., every word spoken by the god is turned into an angel (Hagigah 14a); Sanhedrin $38 \mathrm{~b}$ acknowledges the god's creation of ministering angels, without providing the details.

- \#demonogony - the unit speaks about the creation of a demon, e.g., in Berakhot 61a the deity creates both good and evil yetzer; Pesahim $54 \mathrm{a}-\mathrm{b}$ locates the creation of the demons at the very end of the biblical cosmogony.

- \#monstrogony - the unit speaks about the creation of a monster, e.g., Sotah $48 \mathrm{~b}$ locates the origins of shamir within the first six days of creation (contra: Pesahim 54a); Bava Batra $74 \mathrm{~b}$ retells the creation of the sea-monsters and refers it to Leviathan.

- \#pneumogony - the unit speaks about the creation of a ghost, e.g., in Berakhot $18 \mathrm{~b}$ deceased people turn into ghosts who can be consulted for knowledge; in Moed Qatan 28a Raba becomes a ghost and relates his experiences; the souls to be incarnated are kept under the divine throne (Shabbat 152b and Hagigah 12b).

\section{Relationships between SEs and humans}

The second group of topical tags includes the following topics pertaining to the relationships between SEs and humans.

\#spheresoflife - the unit speaks about the presence of SEs in various domains of human life:

- \#birth - an SE is associated with conception, prenatal development, birth, and the early stages of life, e.g., the ministering angels are well-informed about the stages of the formation of foetuses (Nedarim $20 \mathrm{~b}$ and Sotah 2a); in Bava Metzia 86b Angel Michael announces the birth of Isaac to Sarah.

- \#cosmogony - an SE appears in the context of the creation of the world, e.g., the angelic prince of the sea identified with the monster Rahab swallows all the waters of the world and thus makes room for the divine creation (Bava Batra 74b). 
- \#cuisine - an SE is associated with food, e.g., the demons rest on the crumbs on Wednesday's and Sabbath's nights (Pesahim 111b); qordiaqos, the spirit of dizziness dwells in the new wine (Gittin 67b).

- \#death - an SE is associated with death, e.g., Berakhot $4 \mathrm{~b}$ acknowledges the agility of the angel of death, while Bava Qamma 6ob speaks about his behaviour during the plague; an angel kills a Sadducee in Yoma $19 \mathrm{~b}$.

- \#economy - an SE is associated with material wealth, e.g., a zodiac (Heb. mazal) ${ }^{10}$ decides about the prosperity of a human (Moed Qatan 28a); a man considerate about food leftovers, prevents the intrusion of an angelic prince of poverty into his house (Hullin 105b).

- \#eschatology - an SE is associated with the end of the world and post-mortem existence. ${ }^{11}$

- \#apocatastasis - an SE returns to the god, e.g., the human souls (Heb. ruchot) do so after their life is over (Shabbat 152b).

\# \#ndofdays - an SE appears in eschatological times, e.g., Shabbat 55a interprets the six men of Ezekiel 9:4 as the angels; Leviathan is preserved in salt for the righteous in the world to come (Bava Batra $74 \mathrm{~b}$ ). - \#reincarnation - an SE appears in the context of reincarnation, e.g., Shabbat $152 \mathrm{~b}$ hints at the reincarnation of souls depending on their moral conduct.

\#resurrection - an SE appears in the context of resurrection, e.g., Shabbat $152 \mathrm{~b}$ discusses the bodily form of the deceased before the resurrection; Hagigah $12 \mathrm{~b}$ acknowledges the god's ability to resurrect the deceased humans.

\#underworld - an SE appears in the context of humans' post-mortem existence, e.g., in Sanhedrin 110a-b Gehenna turns its inhabitants "like meat in a pot;" in Sanhedrin 94a angel Dumah governs over the dead.

- \#evacuation - an SE is associated with defecation and urination, e.g., Berakhot 6ob-62a regulates one's toilet behaviour vis-a-vis the demons; after leaving the latrine one is followed by a demon (Gittin 70a).

- \#festivals - an SE is associated with a religious festival.

${ }_{10}$ Mazal together with middah, azazel, belial and several other words remain disputable regarding their status as SEs. They have been included in the database because of the anthropomorphic descriptions in several units, the suggestive usage of these terms in the extra-rabbinic literature and the governing principle of the EvT project to err on the side of inclusivity rather than to miss out on some potential SE. See: Kosior, 2017.

11 This tag has to be distinguished from \# eschatology. The \#death concerns the process of dying, while the \#eschatology concerns the post-mortem existence. 
- \#pesach - an SE is associated with Passover, e.g., during the Passover's "night of guarding" one is safe against the demons (Pesahim 109b and Rosh HaShana 11b).

\#roshhashanah - an SE is associated with New Year, e.g., the blow of shofar confuses Satan in his evil plots (Rosh HaShana 16a-b); the ministering angels do not sing hymns of praise on that day (Rosh HaShana 32b).

- \#sabbath - an SE is associated with the sabbath, e.g., an evil spirit deceives the pious beyond the techum (Eruvin 41b); King David studied scripture every sabbath, which prevented the angel of death from killing him (Shabbat 3ob); Pesahim 54a-b locates the creation of shamir and demons on the night of the first sabbath.

\#sukkot - an SE is associated with Sukkot, e.g., Rabbi Aha ben Jacob used to taunt Satan while performing the waving of lulav ritual (Sukkah 37b-38a).

\#yomkippur - an SE is associated with the Day of Atonement, e.g., Satan has no permission to accuse Israel on Yom Kippur (Yoma $20 \mathrm{a}$ and Nedarim 32a-b).

- \#halakhah -an SE appears in the context of halakhah, cult and theology, e.g., Sanhedrin 101a forbids consulting the demons on shabbats; in Hagigah 15a Rabbi Elisha ben Avuyah questions the principles of monotheism upon encountering angel Metatron in heaven.

- \#marriage - an SE appears in the context of the marital life, e.g., in Moed Qatan 18b bat qol announces the future spouses of the foetuses; a stable marital sexual life guards against Satan's temptations (Qiddushin 29b-30a).

- \#masturbation - an SE is associated with onanism, e.g., Adam creates demons by seminal emission (Eruvin 18b); a man who wilfully arouses himself, provokes his yetzer (Niddah 13b).

- \#medicine - an SE appears in the context of medicine, as responsible for evoking a given condition, helpful in combating it or elimination by medical means.

o \#blindness - an SE is associated with ophthalmological disorder, e.g., the demon shabriri causes blindness (Pesahim 112a, Gittin 69a and Avodah Zarah 12b).

- \#fever - an SE is associated with fever, e.g., Gittin 69b advises the use of an "arrow of Lilith" (Aram. gira deLilita) against fever 
(Aram. gira); the angel of Yahweh is mentioned in a healing spell (Shabbat 67a).

\#hygiene - an SE is associated with hygiene, e.g., Bava Metzia 107b offers dietary choices to keep the demons away; Pesahim 112a warns against the evil spirit infecting beverages left in opened vessels over night; in Hullin 105b-106a a demonic servant of Rabbi Papa checks if the water brought for his master is safe to drink.

\#mental - an SE is associated with psychiatric and neurological disorders, e.g., Rosh HaShana 28a-b discusses the behaviour evoked by a demon; Bekhorot $44 \mathrm{~b}$ identifies demon naalat as responsible for causing epileptic spasms; Satan makes an ox feel uneasy (Berakhot 33a). \#plague - an SE is associated with epidemic diseases, e.g., the angel of death is particularly busy during the plague (Berakhot $4 \mathrm{~b}$ and Bava Qamma 6ob); in Berakhot 62b Satan conjures the plague after David's census; Horayot 1oa speaks about plagues induced by spirits. \#skin - an SE is associated with dermatological diseases and body deformations, e.g., Niddah 22b-24b speaks about a disfigured foetus resembling a sea monster or Lilith; in Megillah 12b Gabriel besets Queen Vashti with psoriasis.

- \#suffering - an SE is associated with an unspecified distressing medical condition, e.g., in Niddah 71a the angel of death causes Queen Esther to menstruate out of fright.

- \#sex - an SE is associated with sexual life, e.g., in Nedarim 2oa-b Rabbi Eliezer is described by his wife as if being compelled by a demon during the execution of his marital duties; in Qiddushin 81a Rabbi Amram withstands the carnal urge and repels yetzer in the form of a fiery column. Two subsequent first-tier topics (\#cooperation and \#antagonism) are based directly on the category of \#attitude, i.e., the general emotional framework for the relationships between SEs and humans of the BT: the "us" of the BT (e.g., rabbis, figures of biblical Israel and Judea, etc.) and "them" (e.g., Persians, Romans, figures of biblical kingdoms surrounding Israel and Judea, etc.). The main governing theoretical principle is that since the SEs are described using anthropomorphic terms, they can be analysed as actors of interpersonal exchanges. These exchanges in turn can be described using the paradigms of primary emotions developed on the grounds of psychology, especially evolutionary psychology (e.g., Buss 2016; Ekman 2003; Lazarus 1994). The \#attitude category contains four tags. 
- \#pos[itive] - an SE increases biological and psychological wellbeing of a human belonging to "us." E.g., it shares esoteric knowledge (e.g., Berakhot 51a; Shabbat 89a; Pesahim 110a), performs various tasks (e.g., Gittin 68b), expresses submission (e.g., Bava Batra 16a) or afflicts "them" (e.g., Gabriel castrates Potiphar in Sotah 13b).

- \#neg[ative] - an SE decreases biological and psychological wellbeing of a human belonging to "us," e.g., it causes unspecified detriment (e.g., Berakhot 3a-b; Eruvin 41b), evokes medical conditions (e.g., Avodah Zarah 12b; Bekhorot 44b), causes various minor nuisances (e.g., Berakhot 6a; Gittin 67b), supports "them" (e.g., Gabriel prepares the land for the future city of Rome in Shabbat 67a).

- \#mix[ed] - an SE exhibits mixed attitude, or the unit speaks about various SEs exhibiting various attitudes, e.g., relationships with the angel of death are ambivalent (Sukkah 53a; Hagigah 4b-5a); Satan enriches spiritually through harsh lessons (e.g., Qiddushin 81a-b); yetzer incites carnality but also secures the population growth (e.g., Berakhot 6ob-61a, Yoma 69b).

- \#uns[pecified] - an SE's attitude remains unspecified, e.g., Berakhot 18b, Eruvin 10ob.

The above outline serves as a semantic envelope for the more specific interactions which unfold within.

\#cooperation - an SE collaborates with a human belonging to "us":

- \#affliction - an SE agonises the humans' enemies, e.g., in Pesahim 118b the stars (Heb. kokhavim) fight against Sisera; in Sanhedrin 94a-b the angels destroy the Assyrian troops besieging Jerusalem; in Bava Metzia 86b Gabriel ravages Sodom.

- \#exchange - an SE helps humans in exchange for something, e.g., in Berakhot $62 \mathrm{~b}$ a human sacrifice is made to appease the angel of destruction; in Bava Metzia 86b the god does to Abraham's sons what Abraham did to his ministering angels.

- \#healing - an SE heals a human, e.g., in Bava Metzia 86b Raphael treats Abraham after circumcision; angels Sharlay and Amarlay are responsible for curing boils and aches. (Shabbat 67a). ${ }^{12}$

12 The \#doctor and \#healing tags are closely related and in the current version of the database they cooccur, even though they are theoretically separable. An SE could possess a skill (hence the \#doctor tag) but not necessarily manifest it in action. Conversely, if an SE heals a human, it is marked with both the \#doctor and the \#healing tags. 
- \#help - an SE helps humans in an unspecified way, e.g., Berakhot 4 b references angelic help mentioned in various places in the Hebrew Bible; in Megillah 15b angels support Queen Esther during her confrontation with King Ahasuerus.

- \#information - an SE shares knowledge with humans, e.g., Angel Suriel teaches demonology to Rabbi Ishmael ben Elisha in Berakhot 51a; in Berakhot 55b Samuel the prophet relies on dreams evoked by angels and demons.

- \#intercession - an SE addresses the god on behalf of a human, e.g., in Pesahim 118a-b angels intercede for the Judeans thrown into furnace; in Sotah 13b the ministering angels applause Moses.

- \#petition - humans ask an SE for intercession, e.g., Shabbat 12b and Sotah 33a suggest addressing the ministering angels in Hebrew rather than in Aramaic; in Avodah Zarah 17a Eleazar ben Dordia entreats the stars and zodiacs for help.

\#antagonism - an SE distresses a human belonging to "us":

- \#hurt - an SE torments a human, e.g., yetzer constantly leads the Judeans astray (Yoma 69b); Satan accuses humans (Yoma 20a).

- \#jealousy - an SE expresses jealousy about a human, e.g., in Sanhedrin 59b the primeval serpent is jealous about Adam's glory, while in Sotah $9 \mathrm{a}-\mathrm{b}$ he desires his wife; in Sanhedrin 103b the ministering angels try to hinder the prophet Micah's approach towards the god; an angel slaps the new-born and makes him forget the whole Torah (Niddah 3ob).

- \#juridical - an SE castigates the moral qualities of a human, e.g., in Berakhot 1b, Moed Qatan 9a, Ketubbot 103b bat qol utters moral judgements while in Taanit 11a and Hagigah 16a this is man's soul or his two guardian angels who testify against him.

- \#possession - an SE controls human or animal behaviour, e.g., Rosh HaShana 28a-b explains mental disorders as evoked by a demon; in Bava Batra 122a a prophet is animated by the holy spirit.

- \#power - the unit speaks about power struggle in relationships.

- \#conflict - an SE and a human try to dominate each other, e.g., in Bava Batra 74b the rabbis struggle with monstrous sea animals; scholars are particularly often exposed to conflicts with yetzer (Sukkah 52a).

- \#control - an SE is subjugated either by a human or by a god, e.g., in Pesahim 112b-113a Rabbi Haninah restricts the range of activities of Igrath bat Mahalath and her angels; in Hullin 92a Jacob wrestles 
with an angel and manages to overcome him; King Solomon compels the heavenly beings (Heb. elyonim), Megillah 11a-b and Sanhedrin 2ob) and Asmodeus (Gittin 68a-b).

\#submission - an SE dominates a human, e.g., a prayer in Berakhot 6ob has the supplicant ask that the yetzer would not coerce him, while Hagigah 16a furnishes a remedy for the situation in which such subjugation has happened..$^{13}$

- \#provocation - a human challenges an SE, e.g., Sukkah 37b-38a and Qiddushin 29b-30a interpret the proverbial "arrow in the eye of Satan" as provocative; Pesahim 110b warns against being too concerned with the demons, so as not to draw their attention.

- \#test - an SE tests a human, e.g., Satan challenges Pelimo in Qiddushin 81a-b, Job in Bava Batra 15b-16a and Abraham and Isaac in Sanhedrin 89b; in Eruvin 54b bat qol puts Rabbi Perada to trial.

- \#trick - a human deceits an SE to attain benefits, e.g., in Berakhot 18b a man eavesdrops on two souls and learns about the future events; in Shabbat 30 K King David prolongs his life by studying Torah and keeping the angel of death away; in Gittin 68a Benaiah tricks Asmodeus into debauchery and dominates the intoxicated demon.

The last first-tier topic speaks about ways of structuring the relationships with the SEs, both by counteracting their antagonism and by inducing them to cooperate.

\#apotropaic - a human uses some means to get away from, repel, destroy or dominate an SE:

- \#amulet - a human affects an SE by means of an amulet (Heb. qamiya or segula), e.g., Shabbat 53b and Pesahim 111b discuss the conditions under which an amulet is effective against SEs.

- \#avoidance - a human evades confrontation with an SE, e.g., Berakhot $3 \mathrm{a}-\mathrm{b}$ heeds against wandering among the ruins inhabited by the demons; in Pesahim 111b Rabbi Kahana refrains from stepping on the shadows so as not to disturb demons.

- \#assistance - a human fends off an SE with the help of another SE, e.g., in Pesahim 119a the winged living creatures protect the supplicant against the divine aspect (Heb. middah) of anger; in Yevamot 102b Gabriel protects against Gehenna.

13 This tag has to be distinguished from \#submission. A SE marked with \#possession takes direct control of the actions of a human or an animal, while an SE marked with \#submission only overpowers its prey. 
- \#binding - a human disables or immobilises an SE, e.g., Yoma 69b, Bava Metzia 32b and Sanhedrin 111b urge to overcome one's yetzer.

- \#circumcision - a human affects an SE by means of circumcision, e.g., in Nedarim 31b-32a Zipporah performs this act on her son and thus repels Satan; in Menahot 43b Rabbi Eliezer proclaims the apotropaic power of brit milah.

- \#citation - a human affects an SE by means of a biblical quotation, e.g., the angel of death can be warded off by quoting Zechariah 3:2 in Berakhot 51a; Psalm 91 chases the demons away in Shevuot 15b.

- \#decency - a human affects an SE by being righteous, e.g., Rabbi Meir drives Satan away by mediating between quarrelling parties in Gittin 52a; in Avodah Zarah 17a-b rabbis Haninah and Jonathan challenge yetzer hara by resisting harlots' allure.

- \#incense - a human affects an SE with a fragrant substance, e.g., in Keritot $3 \mathrm{~b}$ the rabbis discuss whether an incense works as a repellent of a demon or an offering.

- \#invocation - a human asks an SE for assistance against another SE, e.g., Berakhot 6ob encourages people to address the angelic holies (Heb. qadoshim) to attain protection against the demons and to inquire the deity for help in overcoming one's yetzer.

- \#light - a human affects an SE with light, e.g., in Berakhot 43 b a torch fends off the demons while in Shabbat 29b extinguishing a candle allows one to hide from an evil spirit.

- \#magic - a human affects an SE by acting on another object, e.g., Gittin 69a and Avodah Zarah 12b explain how to get rid of shabriri.

- \#mezuzah - a human affects an SE with a mezuzah, e.g., in Avodah Zarah 11a Onkelos convinces the Roman soldiers about the protective power of this item.

- \#name - a human affects an SE with a divine name, e.g., in Sukkah 53a-b King David stops the deep (Heb. tehom) from expanding by casting at it a piece of clay with the word Shadday written on it; in Gittin 68a-b Salomon subjugates Asmodeus with the artefacts inscribed with the divine name.

- \#noise - a human affects an SE by making noise, e.g., if somebody is threatened by an evil spirit an alarm can be made even on sabbath in Taanit 22b.

- \#pairs - a human refrains from doing things in even numbers in order to avoid provoking an SE, e.g., one should not drink even num- 
bers of glasses so as not to become prey to the demons in Pesahim $109 \mathrm{~b}$.

- \#passing - a human transfers through or remains behind a certain point, which cannot be passed by an SE, e.g., the angel of death cannot wade through water in Yoma $77 \mathrm{~b}$ and cannot enter the city of Luz in Sotah $46 b$.

- \#plurality - a human seeks or attains companionship of other humans or their substitutes to affect an SE, e.g., Shabbat $151 \mathrm{~b}$ and Pesahim 112b warn against remaining alone at night; in Berakhot 62a Rabbi Abaye's mother trained a lamb to assist him in his lavatory and thus to repel the satyrs.

- \#prayer - a human prays to affect an SE, e.g., in Yoma 53b a prayer is said to grant general protection; in Sukka 14a and Yevamot 64a a prayer protects against divine aspects.

- \#purification - a human affects an SE by maintaining personal hygiene, e.g., washing one's hands protects against the demoness bat chorin; (Shabbat 109a); a healthy breakfast is an antidote against demons (Bava Metzia 107b).

- \#sign - a human possesses a mark (Heb. ot or tav), either organic or artificial which affects an SE, e.g., in Shabbat 55a Gabriel puts a sign on the righteous' forehead to protect them against the angels of destruction.

- \#spell - a human affects an SE by uttering or writing a non-biblical phrase, e.g., Shabbat 67a contains a spell against shedim; in Avodah Zarah $12 \mathrm{~b}$ the demon shabriri is destroyed by means of a reductionist triangle.

- \#study - a human affects an SE by studying the Torah or Mishnah, e.g., diligent students of the Torah conquer the yetzer (Sanhedrin 111b and Avodah Zarah 5b).

- \#tefillin - a human affects an SE with tefillin, e.g., in Berakhot 23a-b Rabbi Johanan keeps his phylacteries with him in the toilet for the purpose of protection; Gehenna devours those who are negligent about this commandment (Rosh HaShana 17a).

- \#torah - a human affects an SE by possessing a scroll of the Torah or part of it, e.g., the Torah is a countermeasure against evil yetzer (Bava Batra 16a).

- \#tzitzit - a human affects an SE with tzitziyot, e.g., in Menahot 41a the fringes protect Rabbi Kattina from an angel. 


\section{Concluding remarks}

The above presented system of topic tags was developed in a hybrid, partially organic manner. This means that while the general orientation followed theoretical and methodological assumptions, the specific categories were formulated on the go, together with the discovery and analysis of the subsequent textual units. The growth of the tag ontology featured alternating phases of unrestricted proliferation of labels as well as rigid pruning and arranging of the categories and so the system covers only a slice of the literary reality. Moreover, there is a stark disproportion in the popularity of specific tags, with some being particularly rare and as such considered for deletion or exchange for something more abstract, e.g., \#baths, \#bridge and \#palace. While simplifying the system would be desirable, this should not compromise its accuracy - thus the decision to merge or delete these tags has been postponed until the inclusion of texts other than the BT into the EvT inventory. What is more, the above presented system, while more coherent and logical than those previously used, should not be treated as the be all and end all. One of the foundational purposes of the EvT project was to cover a broad range of textual and non-textual materials and since the outset the endeavour had a highly iterative nature. This means that subsequent updates are not only feasible but even anticipated.

\section{Bibliography}

Berry, David M. 2012. Introduction: Understanding the Digital Humanities. In Understanding Digital Humanities, edited by David M. Berry, 1-20. Basingstoke (Hampshire): Palgrave Macmillan.

Buss, David M. 2016. Evolutionary Psychology. The New Science of the Mind. London-New York: Routledge.

Crofts, Nick, Martin Doerr, Tony Gill, Stephen Stead and Matthew Stiff, eds. 2011. Definition of the CIDOC Conceptual Reference Model Produced by the ICOM/CIDOC Documentation Standards Group, Continued by the CIDOC CRM Special Interest Group Version 5.0.4 November 2011. http://www.cidoc-crm.org/html/5.0.4/cidoc-crm.html.

Eide, Øyvind and Christian-Emil Smith Ore. 2020. "Ontologies and Data Modeling." In The Shape of Data in the Digital Humanities. Modeling Texts and Text-based Resources, edited by Julia Flanders, and Fotis Jannidis, 178-196. [S.I.]: Routledge.

Ekman, Paul. 2003. Emotions Inside Out: 130 Years after Darwin's The Expression of the Emotions in Man and Animals. New York: The New York Academy of Sciences.

Elyonim veTachtonim. 2017. https://elyonimvetachtonim.project.uj.edu.pl/.

Fiormonte, Domenico, Teresa Numerico, and Francesca Tomasi. 2015. The Digital Humanist. A Critical Inquiry. Brooklyn: Punctum Books. 
Flanders, Julia, and Fotis Jannidis. 2020. "Glossary." In The Shape of Data in the Digital Humanities. Modeling Texts and Text-based Resources, edited by Julia Flanders, and Fotis Jannidis, 313-333. [S.I.]: Routledge.

Hayles, Nancy Katherine. 2012. "How We Think: Transforming Power and Digital Technologies.” In Understanding Digital Humanities, edited by David M. Berry, 42-66. Basingstoke (Hampshire): Palgrave Macmillan.

Hogan, Patrick Colm. 2003. The Mind and Its Stories. Narrative Universals and Human Emotion. Cambridge: Cambridge University Press.

Hughes, Lorna, Panos Constantopoulos, and Costis Dallas. 2016. "Digital Methods in the Humanities: Understanding and Describing their Use across the Disciplines." In A New Companion to Digital Humanities, edited by Susan Schreibman, Ray Siemens, and John Unsworth, 150-170. Chichester: Wiley Blackwell.

Kosior, Wojciech. 2017. "Elyonim veTachtonim. Some Methodological Considerations on the Electronic Database of Angels, Demons and Ghosts in Early Rabbinic Literature." The Polish Journal of the Arts and Culture, n.s., 5, no 1: 89-112.

Lazarus, Richard. 1994. Emotion and Adaptation. Oxford: Oxford University Press.

McGann, Jerome. 2016. “Marking Texts of Many Dimensions." In A New Companion to Digital Humanities, edited by Susan Schreibman, Ray Siemens, and John Unsworth, 358-377. Chichester: Wiley Blackwell.

Neilson, Tai, Lewis Levenberg, and David Rheams. 2018. "Introduction: Research Methods for the Digital Humanities." In Research Methods for the Digital Humanities, edited by Lewis Levenberg, Tai Neilson, and David Rheams, 1-14. Basingstoke (Hampshire): Palgrave Macmillan.

Rydberg-Cox, Jeffrey A. 2006. Digital Libraries and the Challenges of Digital Humanities. Oxford: Chandos Publishing.

Sperberg-McQueen, C. Michael. 2016. "Classification and Its Structures.” In A New Companion to Digital Humanities, edited by Susan Schreibman, Ray Siemens, and John Unsworth, 377-393. Chichester: Wiley Blackwell.

Wierzbicka, Anna. 1999. Emotions Across Languages and Cultures: Diversity and Universals. Cambridge: Cambridge University Press.

Wierzbicka, Anna. 2014. Imprisoned in English. The Hazards of English as a Default Language. Oxford: Oxford University Press.

Wilkens, Matthew. 2012. "Canons, Close Reading, and the Evolution of Method." In Debates in The Digital Humanities, edited by Matthew K. Gold, 249-258. Minneapolis: University of Minnesota Press. 